\title{
CONTENT ANALYSIS: EXPLORING THE SUITABILITY OF BUSINESS ENGLISH TEXTBOOK FROM LEARNER'S PERSPECTIVE
}

\author{
Pangulu Sudarta Saat \\ Universitas Negeri Jakarta, Jakarta, Indonesia \\ pangulusudarta_pb15s2@mahasiswa.unj.ac.id; \\ Endry Boeriswati \\ Universitas Negeri Jakarta, Jakarta, Indonesia \\ endry.boeriswati@unj.ac.id; \\ Yumna Rasjid \\ Universitas Negeri Jakarta, Jakarta, Indonesia \\ yumna.rasjid@unj.ac.id
}

Accepted: 2020-04-19, Approved: 2020-07-06, Published: 2020-07-20

\begin{abstract}
This research aims to find out how the following aspects of analysis in textbook evaluation can facilitate assessment of the suitability of the text book students have been using as the main course book. The aspects are (1) use of business language skills and grammar (2) business vocabulary (3) business related materials (4) pedagogic features.The textbook being referred to is Market Leader, Third edition, Elementary published by Pearson Education, London, United Kingdom. The gap filled in this research and prior research is that they are prior-use textbook evaluation, while this article is based on a in-use textbook evaluation. To achieve the aim, this research employs Philipp Mayring's Qualitative Content Analysis research method, and Chengqian Guo's new text book evaluation model as the framework developed from previous evaluation models.
\end{abstract}

Keywords: Business English text book suitability; Content Analysis; Textbook evaluation; Phillpp Mayring's Content Analysis; Chengqian Guo's New Textbook Evaluation Model. 


\section{INTRODUCTION}

The application of information technology for communications and development in international trade and international business has eversince intensified globalisation in those areas respectively. The pressure felt by nations participating in international business is primarily in improving communication competence of their people engaged in day-to-day business operations. This said competence can be achieved by having people go through learning and training in Business English.

The quality of Business English courses rely heavily on two elements. The first and formost are the quality of language instructors, and followed by the quality of the teaching materials, in particular the textbooks that the instructors and the course participants use. Assessing the quality of courses involve two proposed steps. The first step is evaluating the suitability of the textbook being used in the course. Should evaluation findings indicate that the textbook suits as a coursebook, then its use by the instructors shall be continued. Otherwise, other textbook(s) shall be considered to substitute. The second step proposed is evaluating the quality of the suitable textbook. This article shall focus on presenting evaluation of the suitability of a given Business English textbook to perform as a Business English coursebook, and not yet to present the quality of the textbook.

Aspects of analysis in a textbook evaluation in this research consists of (1) use of business language skills and grammar (2) business vocabulary (3) business related materials (4) pedagogic features. Measuring suitability of a textbook involves comparing its contents to a set of criteria. Sets of criteria are obtained from theoretical propositions made by experts in the field of teaching material development and teaching material evaluation.

There are various definitions on the 
BAHTERA: Jurnal Pendidikan Bahasa dan Sastra, Volume 19 Nomor 2 Juli 2020

http://journal.unj.ac.id/unj/index.php/bahtera/

P-ISSN : 0853-2710

E-ISSN : 2540-8968

term suitability from the perspective of its

learners of Business English.

performance as a coursebook; nevertheless,

Piotr Romanowsky (Romanowski, the term used here is taken from one coined by Hutchinsons and Waters. Hutchinsons and Waters in Dali Ning (Ning, 2019) defined textbook suitability as "the measure of fullfillment of a book against the a set of requirements for the book to perform as a coursebook."

Business English is a part of of English for Specific Purposes. It is English primarily used by people engaged in international business. These people have a set of communication needs unique to these users of English. Maia Kutateladze in her research has identified several needs of these people namely the need to engage in internatinal business negotiations, to present a business proposal or a product, or to converse in social functions attached to business. Kutateladze further asserts (Kutateladze, 2014), that it is the very needs of these people which navigate textbook writers in designing textbooks intended for Business English coursebooks - why and how to evaluate them, évfolyam 2016) wrote an article in a journal entitled "Business Coursebooks - why and how to evaluate them," In Romanowsky's study, he proposed checklists designed as instruments specifically for evaluating Business English textbooks. His instruments considers various aspects of analysis for textbook evaluation, namely the content aspect of the textbook, the methodological aspect of of the textbook, and several other aspects of analysis proposed by the experts. In relation to this article, Romanowsky's research became an inspiration in determining the aspects of analysis introduced in this article.

Another work referenced here is one that was presented in researchgate https://www.researchgate.net/publication/25 0002927_Textbook_evaluation_as_an_essenti al_part_of_business_English_teacher'_s_prof essional_competence) was a research by 
BAHTERA: Jurnal Pendidikan Bahasa dan Sastra, Volume 19 Nomor 2 Juli 2020

http://journal.unj.ac.id/unj/index.php/bahtera/

P-ISSN : 0853-2710

E-ISSN : 2540-8968

Slavica Cepon from University of

mentions that these elements are grammar Ljubljana, Faculty of Economics, Slovenia, competence, discourse competence, entitled "Textbook evaluation as an sociolinguistic competence, and strategic essential part of BE teachers' professional competence”. Cepon discusses how teachers assess Business English textbooks (Cepon, 2004). She studied three Business English textbooks, and her findings were that for teachers evaluating Business English textbooks, employing objective categories is easier than employing subjective categories. The difference between Cepon's research and this research is that her research is a prior-use textbook evaluation, while this article is based on a in-use textbook evaluation.

A relevant research was done by Nicolae Adina. Adina's research inspired the writing of this article. In her article entitled "Limits Of Current Practice In Teaching BE", she exposed elements found in communication competence learning models. Adina citing Canale, Swain, dan Bahman (Adina, 2012)

Khalid, Zafar, dan Saeed in their article entitled Textbook evaluation through quality indicators: The Case of Pakistan, employes (Khalid Mahmood, Muhammad Zafar Iqbal, Muhammad Saeed, 2009) Garvin's quality dimensions to measure the quality of texbooks. As indicated early in this article, quality does 
not equate suitability; nevertheless, many of Garvin's dimension employed by Khalid , Zafar, dan Saeed are similar to the textbook suitablity criteria. This article it different from Khalid, Zafar, dan Saeed's research in the sense that their research does not evaluate any particular textbook.

Mutiara Ayu and Rita Indrawati from Universitas Teknokrat Indonesia wrote an article (Mutiara Ayu \& Rita Indrawati, 2018) published in researchgate entitled EFL Textbook Evaluation: The Analysis of Task Presented in English

Textbooks. The difference between this article and the one written by Mutiara Ayu et. al. lies in the learning process researched. Mutiara Ayu et. al. evaluated an EFL textbook, while this article evaluated an ESP textbook. Futhermore, Mutiara Ayu et.al. research focused on the pedagogic aspect only, namely the features of the exercises and tasks contained in the textbook. On the other hand, this article focuses on four aspects namely (1) use of business language skills and grammar (2) business vocabulary (3) business related materials (4) pedagogic features.

Another relevant article is one entitled An Empirical Study on Business English Teaching and Development by Dai Guiyu dan Liu Yang. (Dai Guiyu \& Liu Yang, 2016). The similarities of the article written by Dai dan Liu with this article is that both articles develop their research on needs analysis of Business English learners. The difference lies in the purpose of the research. Dai and Liu's article dwells on new findings in needs analysis in learning meanwhile this article focuses on use of business language, business vocabulary and lexis, business contents and business related learning materials, and pedagogic features.

\section{FOCUS OF THIS STUDY}

This study focuses on aspects of analysis in textbook evaluation. The aspects should help direct the evaluator to put the needs of 
the learner-users of the coursebook into logical categories. Romanowski quoting Frendo asserts that (Romanowski, 2017) in the case of teaching in-company Business English courses, these courses imply taking into consideration the sponsors perspective and/or demand on what should be covered during the course. Sponsors perspective would commonly entail issues such as capacitiy of the employees to generate more profit, be more motivated, be better negotiators, better presenters, or managers.

Based on the aforementioned background, this article focuses more on the results of observing four aspects of analysis unique to evaluating textbooks designed for use as Business English coursebooks, i.e. (1) use of business language skills and grammar (2) business vocabulary (3) business related materials (4) pedagogic features.

THEORETICAL BENEFIT OF THIS STUDY
Mayring's Qualitative Content Analysis implemented to Guo's new textbook evaluation model used in this study could help foreign language courses and teachers perform a systematic yet relatively simple textbook evaluation to assess a textbook's suitability as a coursebook.

\section{EVALUATION METHOD AND}

\section{MODEL}

The research approach employed is qualitative, and the method used is the deductive approach in Philipp Mayring's Content Analysis (Mayring, 2004). The evaluation model employed is the new textbook evaluation model developed by Chengqian Guo (Guo, 2018).

Mayring's method begins with raising the research questions on what will be the aspects of analysis in the evaluation process. This is followed by theoreticallybased assigning the definitions to each and every aspect of analysis. Once the aspects are determined and defined, main 
categories and sub categories need to be assigned to each aspect. Theoretically, learner's needs become the basis for determining the aspect of analysis to evaluate textual and content suitability of any sort of textbook. In particular to Business English textbooks, there are four aspects, namely (1) the need to improve familiarity with grammar and improve skills in use of language, (2) the need to improve familiarity with business vocabulary, (3) the need to improve familiarity with business related content, and (4) the need of learning materials (this research focus solely on textbooks) having pedagogic features.

Mayring's method thus prescribes that to be able to assign main and or subcategories to the aspects of analysis, an evaluation model is required as a reference. In this research, Guo's new textbook evaluation model is employed. Guo's model is basically a combination of two existing evaluation models namely one proposed by Cunningsworth and one by Littlejohn. Guo's model puts the four aspects of analysis into eight main categories:

\section{Input}

II. Layout

III. Supplementary materials

IV. Goals and Objectives

V. Learners

VI. Teaching methods and Teachers

VII. Teaching environment

VIII. Practical considerations

Each main category shall be the evaluators guide in selecting text suitability criteria. Sources of these criteria are obtained from literature studies containing theoretical propositions from material evaluation experts. Take for example the main category "input". The main category of input can be assigned to (1) the aspect of language skills i.e. grammar and use of 
language, (2) the aspect of business vocabulary, and (3) the aspect of business contents. From literature studies, CelceMurcia (1979), and also Cunningsworth (1995) proposes a criterion of the content suitability can be checked by analising whether the language level content is appropriate for the learner's level the textbook was intended for. Regarding criterion on business vocabulary input, Romanowsky (2016) asserts that the vocabulary content should facilitate core business communication skills, namely telephoning, $\quad$ socialising, giving presentations, taking part in meetings, negotiating et cetera. Last but not least, the criteria on business content suitability. Mukundan, et.al., (2011) proposes that a criteria that suitability can be checked against authenticy of materials and of situations.

Once sets of criteria are prepared, they shall be used as guidelins in designing the questionnaires that can elicit learners using the text book express their experience in using the book as a coursebook. This method is to be repeated with the aspects of pedagogic features of the text book. At this point then, the evaluator will have a fairlywell idea on the suitability of the text book being evaluated.

\section{PROCEDURE}

The procedure of this research involves three steps. The first step is data collecting through sending questionnaire to learners that are using the textbook that is being evaluated. The questionnaire is designed to elicit responses from the respondents to give their opinions about the textbook they have been using as their coursebook. The respondents opinions that were elicited fall into seven areas, namely (1) content areas (2) activity areas (3) the role of textbook area from the learner-user point of view, expressed metaforically (4) areas representing the engagement of learnerusers towards the textbook, expressed by 
statements about how often and in what occassions they use the book (5) pedagogic areas of the supporting materials attached to the textbook, expressed through responses on whether or not they use those supporting materials (6) areas of the senses, represented by the opinions of the learnerusers about the layout of the textbook (7) areas of learner-users aspiration regarding ideal features of a coursebook.

The second step is data coding. Data coding is done by preparing a Category Coding Agenda Table. This table is a data categorisation instrument that contains categories prepared in Chengqian Guo's textbook evaluation model. The categories are divided into Main Categories, and for each Main Category, Sub Categories are assigned to it. The Main Categories groups aspects of analysis of the textbook being evaluated, and each category is given a definition. Next, the sub categories serve as guidance when identifying the qualitative data. These qualitative data will be compared against relevant criteria obtained from literature review dan from the research data collected from questionnaires.

After the qualitative data identification is done, a coding rule is made. Coding rules contain narratives to be used as reference when the textbook evaluator is conducting documentation review of the data during the evaluation process. 


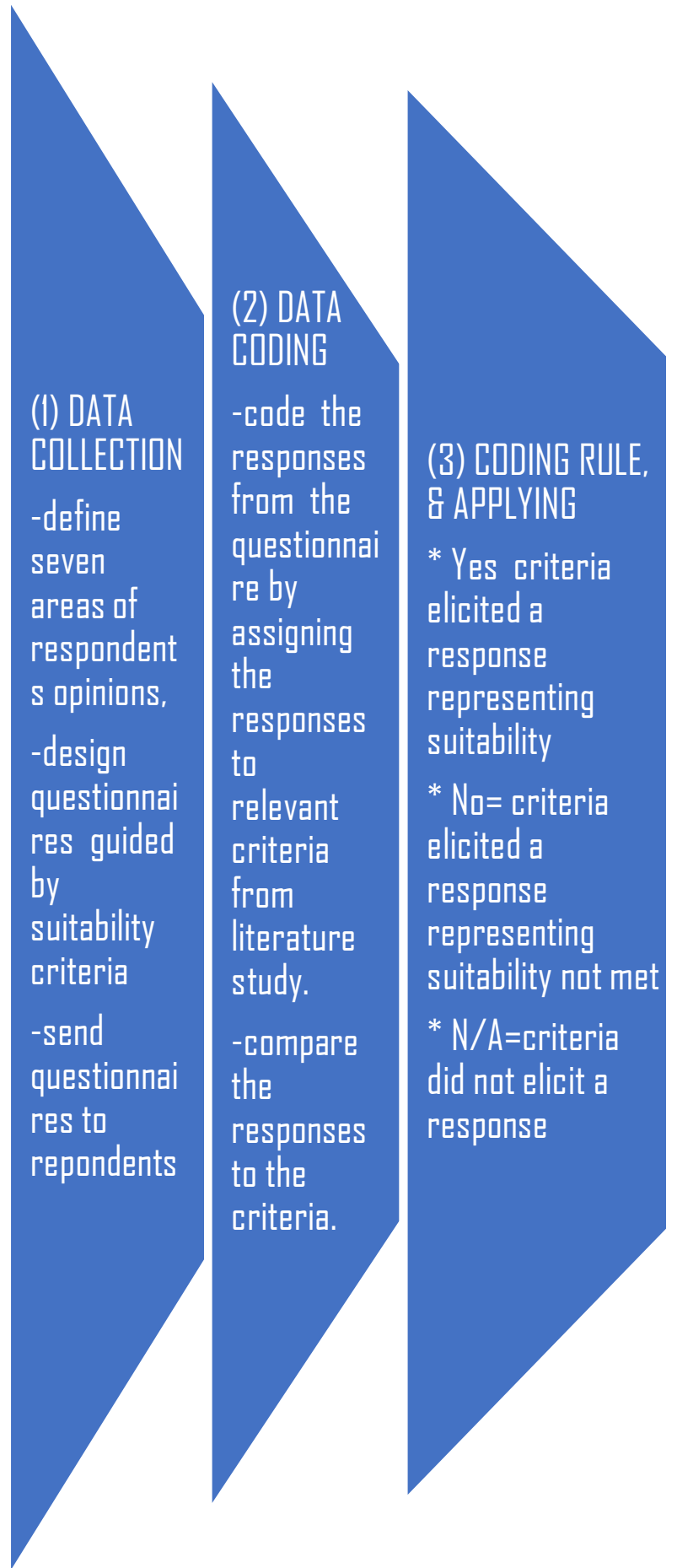




\section{DATA ANALYSIS}

The data analysed originates from the texts contained in the textbook being evaluated. The criteria used to evaluate the textbook suitability originates from two sources. The first source is suitability criteria in the form of theoretical propositions, and the second source is the opinions of the 52 respondents who are learner-users of the coursebook being evaluated. Finally, the measurement of suitability fullfillment is measured using a simple formula developed by Chengqian Guo as follow:

\section{Suitability Measure against Criteria \\ $=(\#$ of Yes $) * 1+(\#$ of No $) *(-1)+(\#$ N/A $) * 0)$}

'Yes' means criteria fullfilled (score given $=1$ ) 'No' means criteria not fullfilled (score given $=$ 1)

'N/A' means the criteria is not applicable to this textbook, or the textbook was neutral - it neither fullfilled nor failed to fullfill the criteria. (score given $=0$ )
From literature review there were 10 theoretical proposition that represent criteria to analyse aspect of business related content/ material in the textbook, 6 theoretical propositions that represent criteria to analyse aspect of grammar and use of (business) language, and 54 theoretical propositions that represent criteria to analyse pedagogic features in the textbook, making a grand total of 70 criteria to analyse aspects of analysis of the text book altogether.

\section{(RESULT AND DISCUSSION)}

After applying the suitability measure againts criteria to the comparison between the responses from the questionnaire and the criteria from the literature review, the findings were as follows:

1. The score from the 10 theoretical propositions that represent criteria to analyse aspect of business related content/material in the textbook is 10 
Yes*(1) +0 No*(-1) +0 N/A * (0) equals

10. This can be construed that the business related contents in this text book is fully suitable for learners at this level of English competence.

2. The score from the 6 theoretical propositions that represent criteria to analyse aspect of grammar and use of (business) language, is 5 Yes*(1) +0 No*(-1) + 1 N/A * (0) equals 5 . This can be construed that the aspect of grammar and use of (business) language in this text book is suitable for learners at this level of English competence.

3. The score from the 54 theoretical propositions that represent criteria to analyse pedagogic features in the textbook is $30 \mathrm{Yes}^{*}(1)+11 \mathrm{No} *(-1)+14 \mathrm{~N} / \mathrm{A} *(0)$ equals 19. This can be construed that pedagogic features in this text book is suitable for learners at this level of English competence.

\section{CONCLUSION}

As far as respondents whom were Business English course learner-users at Lembaga Bahasa Internasional Fakultas Ilmu Pengetahuan Budaya Universitas Indonesia are concerned, the book did not fullfill all suitability criteria. Some learners expect language course book should be abel to serve as self-directed learning material and this text book is still considered to lacks sufficient guidance to be used as selflearning material. They feel that the presence of an instructor is still needed.

A number of respondents responses express concerns on the lack of relationship between examinations and cxcercises in the text book. This finding serves more as an input to the management of the course administrators to observe relevance when designing examination materials. Although revision materials are supplied in this textbook, respondents seem to expect that Business English text books should contain more of it. 
Another finding is that most respondents feel teachers should adapt learning materials for each an every lesson. Business trends constantly and rapidly change, and teacher's creativity play a signifincant role to make the learning successful.

Learners seem to need more content relevant social and cultural context. Learners feel that the text is driven by western values of business operations.

These findings are valuable input for the writers and publishers. They might consider it due-time to launch the next edition of the textbook. Despite these drawbacks, the text book is suitable as a general coursebook to be used for Business English courses.

\section{References}

Adina, N. O. (2012). The limits of current practices in teaching English for Business and Economics. Journal of Education Sciences \&

Psychology, II (LXIV)(1), 99 - 109.

Capkova, Halka and Kroupova, Jarmila. (2017). Language Needs Analysis of Students of Economics. ERIES, 10(1).

Cepon, S. (2004). Textbook evaluation as an essential part of BE teachers' professional competence. Retrieved from

(https://www.researchgate.net/publ ication/250002927_Textbook_eval uation_as_an_essential_part_of_bu siness_English_teacher'_s_professi onal_competence).

Dai Guiyu \& Liu Yang. (2016). An Empirical Study on Business English Teaching and Development. Higher Education Studies, 6 (2). doi:10.5539/hes.v6n2p142

Guo, C. (2018). Fit for purpose? "A New Approach to Evaluating the 
BAHTERA: Jurnal Pendidikan Bahasa dan Sastra, Volume 19 Nomor 2 Juli 2020 http://journal.unj.ac.id/unj/index.php/bahtera/

P-ISSN : 0853-2710

E-ISSN : 2540-8968

suitability of Teaching of Chinese

as a foreign language in the UK".

University of Sheffield. Sheffield,

UK: University of Sheffield.

Khalid Mahmood, Muhammad Zafar

Iqbal, Muhammad Saeed. (2009,

December). Textbook Evaluation

Through Quality Indicators:The

Case of Pakistan. Bulletin of

Education and Research, 31(2), 1-

27.

Kutateladze, M. (2014). Historical Review of Business English as a Part of English. Journal in Humanities , Volume 3(Issue 1), 28.

Mayring, P. (2004). Qualitative Research pp.3. Retrieved June 25th, 2019, from Qualitative Content Analyisis Forum : http//www/Qualitative research

Mutiara Ayu \& Rita Indrawati. (2018). EFL Textbook Evaluation: The Analysis of Task Presented in
English Textbooks.

TEKNOSASTIK, 16(1). Retrieved

from

https://www.researchgate.net/publi cation/329085381

Ning, D. (2019, June). The Suitability of EAP Textbooks to the Learning Needs inChinese Context-From a Pre-Use Perspective. Education Quarterly Reviews, Vol.2, No.2, (2), 305-320.

doi:10.31014/aior.1993.02.02.63

Romanowski, P. (2017). Proposing a comprehensive framework for needs analysis in ESP - the integrality of needs analysis in Business English Course Design. GLOTTODIDACTICA XLIV/2 (2017), XLIV(2), 148-159. doi:10.14746/g1.2017.44.2.09

Romanowski, P. (évfolyam 2016, 1). Business English coursebooks why and how to evaluate them. 
BAHTERA: Jurnal Pendidikan Bahasa dan Sastra, Volume 19 Nomor 2 Juli 2020 http://journal.unj.ac.id/unj/index.php/bahtera/

P-ISSN : 0853-2710

E-ISSN : 2540-8968

Alkalmazott Nyelvtudomány,, XVI.

doi:doi:http://dx.doi.org/10.18460/

ANY.2016.1.003 